\title{
Efficacy of telmisartan and enalapril in patients with diabetic nephropathy
}

\begin{abstract}
Introduction: Diabetic nephropathy is characterized by hypertension and persistent proteinuria and is the leading cause of end stage renal disease (ESRD). The comparison of Telmisartan and Enalapril was designed to assess and compare the efficacies of both drugs in diabetic nephropathy patients.
\end{abstract}

Material and methods: All age groups of patients diagnosed with diabetic nephropathy are included in our study.

Results: 112 patients were recruited in the study. Patients taking Telmisartan and Enalapril once daily completed the study. There was a significant reduction in urine albumin, urine creatinine, urine albumin/creatinine ratio (UACR), serum creatinine, Blood pressure, Fasting blood sugar, Post lunch blood sugar, HbA1C, Total cholesterol, low density lipoprotein, very low density lipoprotein, high density lipoprotein and triglycerides.

Conclusion: Both Telmisartan and Enalapril were efficacious in diabetic nephropathy patients, but Enalapril showed more Reno protection than Telmisartan in this study.
Volume 9 Issue 2 - 2019

Siva Subrahmanyam B, 'Akhil D, ${ }^{2}$ Haripriya

$\mathrm{K},{ }^{2}$ Suresh $\mathrm{T}^{2}$ Venkateshwarlu $\mathrm{E},{ }^{2}$ Ashrith Reddy $\mathrm{Ch}^{3}{ }^{3}$ Sharvana Bhava BS ${ }^{2}$

'Sri Bhadrakali Diabetic Clinic, India

${ }^{2}$ Department of Clinical Pharmacy \& Pharm D, Vaagdevi College of Pharmacy, India

${ }^{3}$ Rakshith Multispeciality Hospital, India

Correspondence: Bandaru Shesagiri Sharvana bhava, Associate professor, Department of Clinical Pharmacy \& Pharm D, Vaagdevi College of Pharmacy, Warangal, Telangana, India, Email sharavanabhava6@gmail.com

Received: March 13,2019 | Published: April 16, 2019

Keywords: diabetic nephropathy, ESRD, telmisartan, enalapril, proteinuria

\section{Background and aim}

Diabetes mellitus is a metabolic complex disorder characterised by hyperglycaemia and glucose intolerance as their hallmark due to insulin deficiency or impaired effectiveness of insulin action. ${ }^{1}$ Diabetic nephropathy is one of the potential micro vascular complications in diabetic patients. It is the leading cause of End stage renal disease (ESRD). Diabetic kidney disease refers to chronic kidney disease (CKD) presumed to be caused by diabetes. ${ }^{2}$ Diabetic nephropathy is screened for persistent abnormal urine albumin excretion and by decreased glomerular filtration rate (GFR). Albuminuria has been divided into micro albuminuria (urine albumin creatinine ratio (UACR) $30-300 \mathrm{mg} / \mathrm{dl}$ ) and macro albuminuria (UACR more than $300 \mathrm{mg} / \mathrm{dl}$ ). Serum creatinine derives estimates of GRF and diabetic kidney disease. ${ }^{3}$

Diabetic kidney disease can be detected by screening for persistent abnormal urine albumin excretion and by determining the estimated glomerular filtration rate. The main evidence based strategies for preventing or delaying loss of kidney function in diabetic patients include blood pressure control, blockade of reninangiotensin system, and glycaemic control. Controlling these factors and reducing proteinuria are now the main focus of diabetic kidney disease management. Through a multidisciplinary approach of implementing guidelines and timely referral, care of the diabetic kidney disease patient can be improved. The key is preventing and slowing the progression of this complication, to keep the other shoe from dropping. ${ }^{4,5}$

The aim of the study is to assess and compare the efficacy of Telmisartan andEnalapril in diabetic nephropathic patients. Angiotensin converting enzyme inhibitors and angiotensin receptor blocker have reno protection effects in diabetic patients. Enalapril; Angiotensinconverting-enzyme (ACE) inhibitors, which competitively block the renin-angiotensin system, decrease glomerular capillary pressure and prevent the progression of microalbuminuria to overt proteinuria. ${ }^{6}$
The side effects of enalapril are Edema, Dry cough, Dizziness, Hypertension, Syncope. Enalapril is contraindicated in pregnancy and breast feeding. Telmisartan is a angiotensin receptor antagonist possessing selective, and insurmountable inhibitory activity specific to the angiotensin $\Pi$ type 1 (AT1) Receptor. ${ }^{7}$ side effects are Tachycardia, Bradycardia, Hypotension, Edema and Allergic reactions. Telmisartan is contraindicated during pregnancy, in bilateral renal artery stenosis in which it can cause renal failure.

\section{Literature}

(Table 1)..$^{8-11}$

\begin{tabular}{|c|c|c|c|}
\hline Author & Year & Study & Conclusion \\
\hline $\begin{array}{l}\text { Roland } \\
\text { et al. }{ }^{8}\end{array}$ & 2013 & $\begin{array}{l}\text { Telmisartan in } \\
\text { incipient and overt } \\
\text { diabetic renal disease. }\end{array}$ & $\begin{array}{l}\text { The Effect of telmisartan } \\
\text { on kidney function support } \\
\text { its use in patients with } \\
\text { microalbuminuria or overt } \\
\text { diabetic nephropathy. }\end{array}$ \\
\hline $\begin{array}{l}\text { Bhansali } \\
\text { et al. }{ }^{9}\end{array}$ & 2010 & $\begin{array}{l}\text { Antialbumineric } \\
\text { efficacy of ACE } \\
\text { inhibitors and ARB'S } \\
\text { in type I DM with } \\
\text { nephropathy. }\end{array}$ & $\begin{array}{l}\text { Dual blockade with } \\
\text { ramipril enhanced with } \\
\text { antialbumineric effect of } \\
\text { telmisartan and reduced in } \\
\text { blood pressure. }\end{array}$ \\
\hline $\begin{array}{l}\text { Anthony } \\
\text { et al. }{ }^{10}\end{array}$ & 2004 & $\begin{array}{l}\text { ARB'S versus ACE } \\
\text { inhibitors in type } 2 \\
\text { DM and nephropathy. }\end{array}$ & $\begin{array}{l}\text { Telmisartan is not inferior } \\
\text { to enalapril in providing long } \\
\text { term reno protection in } \\
\text { persons with type } 2 \text { diabetes } \\
\text { mellitus. }\end{array}$ \\
\hline $\begin{array}{l}\text { Johnsen } \\
\text { et al." }\end{array}$ & 1992 & $\begin{array}{l}\text { Renal protective } \\
\text { effect of enalapril in } \\
\text { diabetic nephropathy }\end{array}$ & $\begin{array}{l}\text { Treatment with enalapril can } \\
\text { reduce the rate of decline in } \\
\text { kidney function in patients } \\
\text { with diabetic nephropathy. }\end{array}$ \\
\hline
\end{tabular}




\section{Materials and methods}

It is a prospective and observational research done in "SRI BHADRAKALI DIABETIC CLINIC" Naimnagar, Hanamakonda and Rakshith Multispeciality Hospital, Kakaji Colony, Warangal, Telangana, India. Patients were explained about the study \& informed consent forms were seeked by explaining them in their local language. Institutional Human Ethical Committee Endorsement was obtained after submission of protocol and IHEC NO. is MGM/VCOP/ PHARMD/V/011/2018.

\section{Inclusion criteria}

a. Patients with diabetes treated by diet or/and oral hypoglycaemic agents or insulin.

b. Patients were required to have glycosylated haemoglobin (HbA1C).

c. Patients who have mild to moderate hypertension.

\section{Exclusion criteria}

a. Any clinical neurological disorder, medical or psychiatric conditions that would interfere with the patient's ability to participate in the study.

b. History of compound abuse or dependence in the past year except nicotine and caffeine.

c. Pregnant or breast feeding women or any psychological conditions that might compromise participation in the study.

d. Patients with renal dysfunction not due to diabetes, a single kidney or known renal artery stenosis, congestive heart failure. ${ }^{12}$

\section{Study design}

It is a prospective, observational, comparative study design, and the patients who are taking Telmisartan and Enalapril were included.

\section{Clinical response assessment}

The efficacy of Telmisartan and Enalapril was assessed by measuring the change in urine micro albuminuria, serum creatinine, Blood pressure, fasting blood sugar, post lunch blood sugar, $\mathrm{HbA}_{1} \mathrm{C}$, Total cholesterol, low density lipoprotein, very low density lipoprotein, high density lipoprotein and triglycerides after 12 weeks of treatment. Primary end point was change in urine albuminuria, urine creatinine, urine albumin/creatinine ratio (UACR) and serum creatinine. Secondary end point was change in blood pressure, fasting blood sugar, post lunch blood sugar, $\mathrm{HbA}_{1} \mathrm{C}$, total cholesterol, high density lipoprotein, very low density lipoprotein, low density lipoprotein, and triglycerides were measured at 12 weeks compared to the baseline levels.

\section{Statistical analysis}

All the parameters were expressed as mean $\pm \mathrm{SD}$ was performed by using the MS-EXCEL sheet 2013. All the parameters were obtained at baseline at the end of study.

\section{Results}

(Figures 1-15).

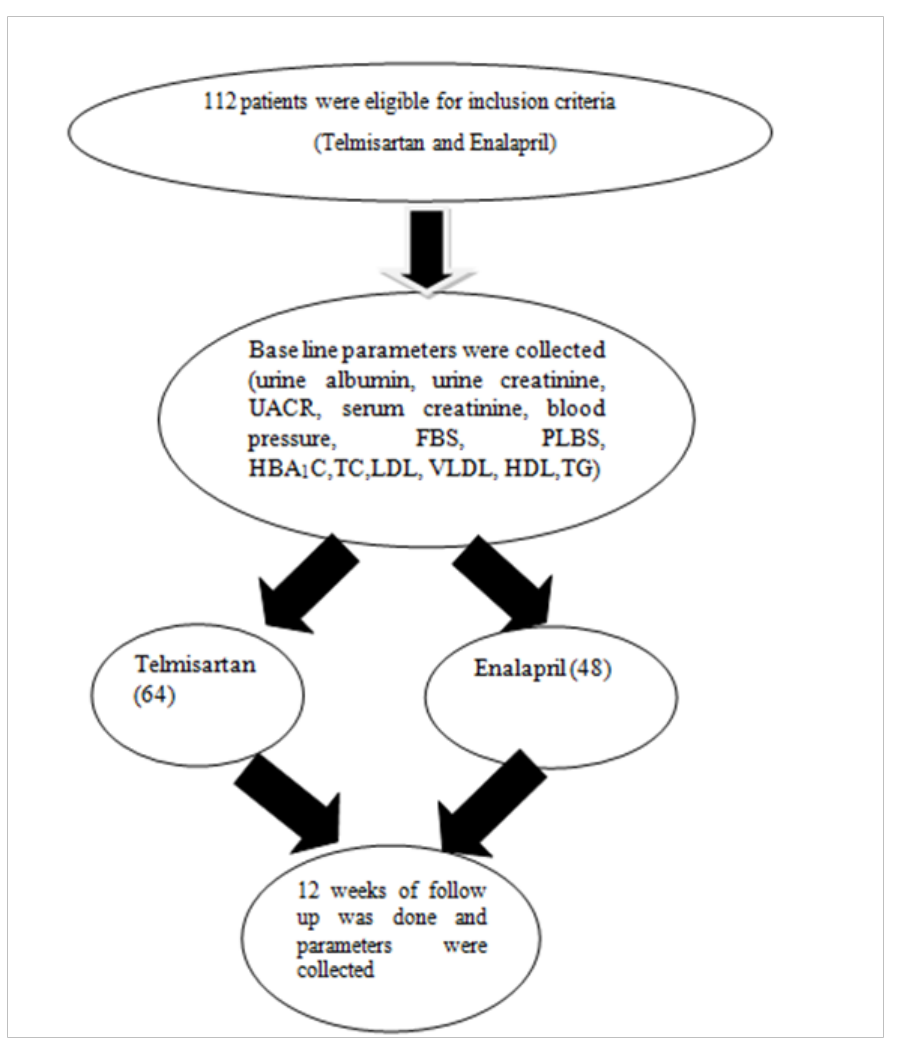

Figure I Distribution of patients.

Mean change of urine albumin in Telmisartan group was $27.09 \pm 31.56$

Mean change of urine albumin in Enalapril group was $27.09 \pm 25.70$

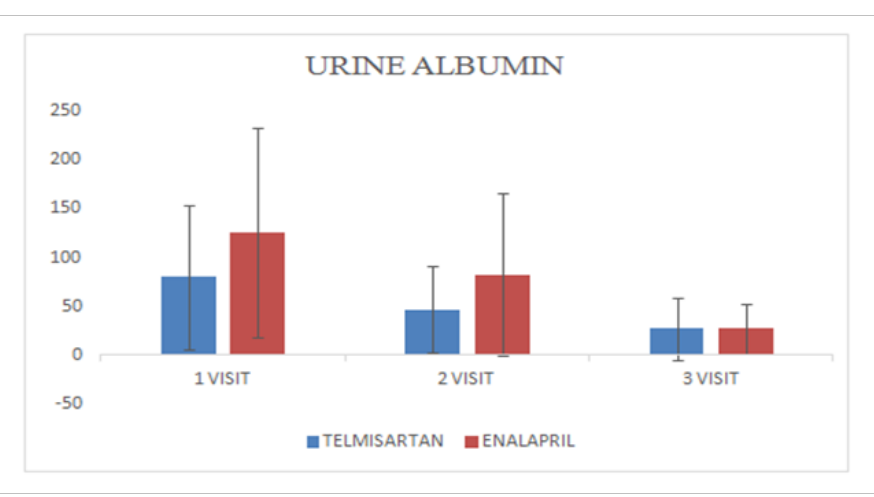

Figure 2 Urine Albumin.

Mean change of urine creatinine in Telmisartan group was $0.94 \pm 0.4$

Mean change of urine creatinine in Enalapril group was $0.83 \pm 0.26$

\section{Discussion}

Comparision of efficacy of Telmisartan and Enlapril was done in patients with diabetic nephropathy. The following glycemic parametresblood pressuresystemic blood pressure,diastolicfasting blood sugar, post lunch blood sugar, $\mathrm{HbA}_{1} \mathrm{C}$,micro albuminuria (urine albumin, urine creatinine, urine albumin /creatinine ratio $[\mathrm{UACR}])$,total cholesterol, high density lipoprotein, very low density 
lipoprotein, low density lipoprotein, and triglycerides were obsereved. To our knowledge, there has been one clinical study that has directly compared the effect of an angiotensin II-receptor blocker (losartan) with that of an ACE inhibitor (enalapril) in subjects with type 2 diabetes and early nephropathy. ${ }^{13}$ That short-term study indicated that both drugs reduced urinary albumin excretion; differences between the treatments were not significant. In our study Telmisartan and Enalapril therapy from baseline to visit-3 has shown a greater efficacy in both groups but enlapril group is more efficacious in decreaseing the microalbuminuria levels than telmisartan group.

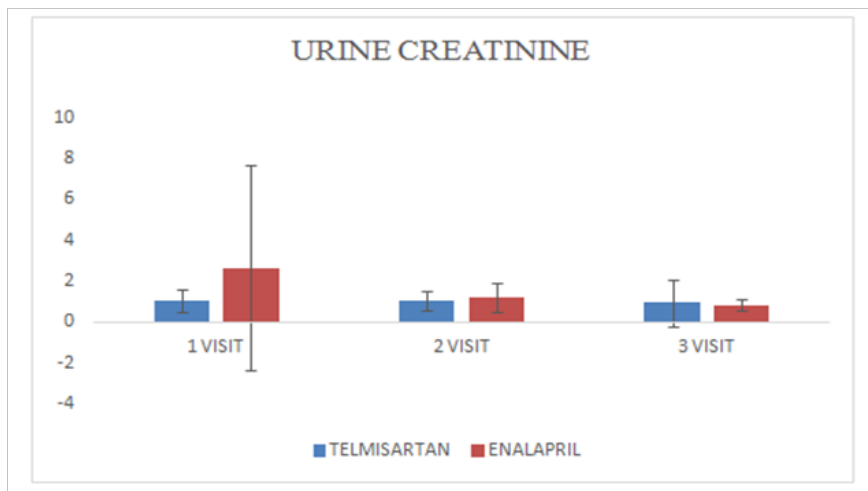

Figure 3 Urine Creatinine.

Mean change of urine albumin/creatinine ratio in Telmisartan group was $22.89 \pm 21.3$

Mean change of urine albumin/creatinine ratio in Enalapril group was $9.7 \pm 3.21$

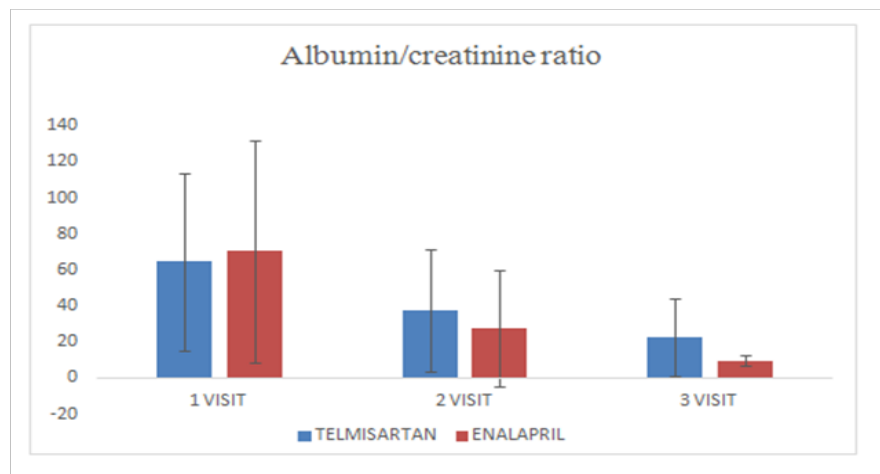

Figure 4 Urine albumin/creatinine ratio (uacr).

Mean change of serum creatinine in Telmisartan group was $1.0 \pm 1.17$

Mean change of serum creatinine in Enalapril group was $0.09 \pm 0.34$.

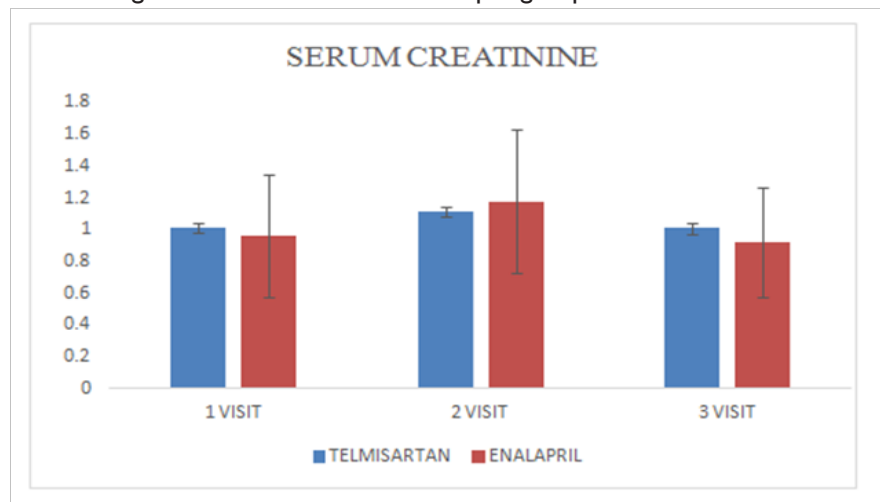

Figure 5 Serum Creatinine.

Mean change of systolic blood pressure in Telmisartan group was $130.64 \pm 7.6$

Mean change of systolic blood pressure in Enalapril group was $134.54 \pm 9.98$

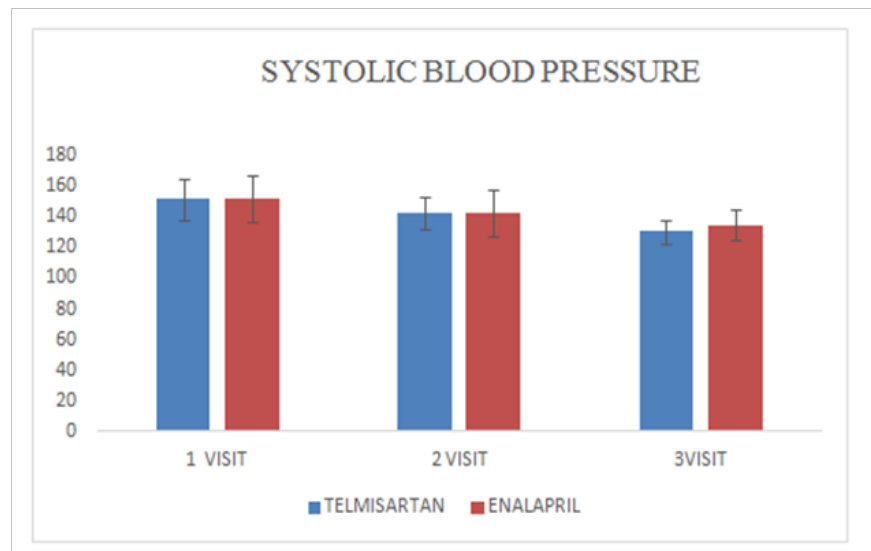

Figure 6 Systolic Blood Pressure.

Mean change of diastolic blood pressure in Telmisartan group was $75.65 \pm 9.98$

Mean change of diastolic blood pressure in Enalapril group was 82.5 \pm 8.94

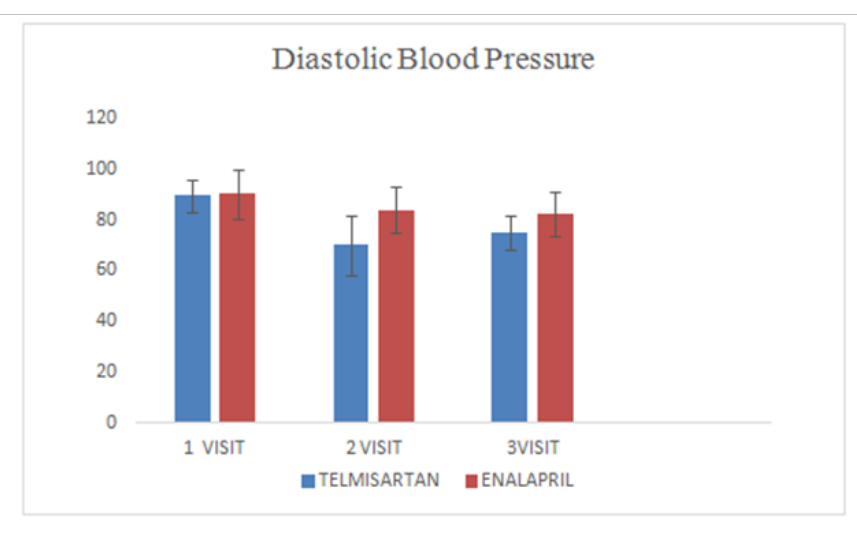

Figure 7 Diastolic blood pressure.

Mean change offasting blood sugar in Telmisartan group was $128.29 \pm 43.07$

Mean change offasting blood sugar in Enalapril group was $122.63 \pm 30.90$

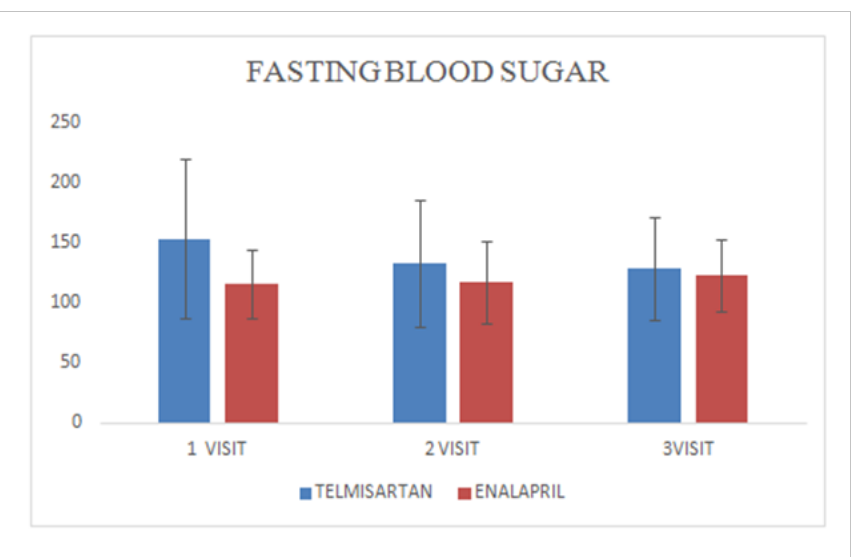

Figure 8 Fasting Blood Sugar.

Mean change of post lunch blood sugar in Telmisartan group was I 80.4 48.90

Mean change of post lunch blood sugar in Enalapril group was $173 \pm 59.90$

\section{Conclusion}

Both Telmisartan and Enalapril were efficacious in diabetic nephropathy patients, but Enalapril confers more reno protection when compared with Telmisartan. This study helps Clinicians in making 
selection of an effective drug between an ACE inhibitor and an ARB, but Clinicians should consider side effects and contraindications while prescribing these drugs in diabetic nephropathy patients.

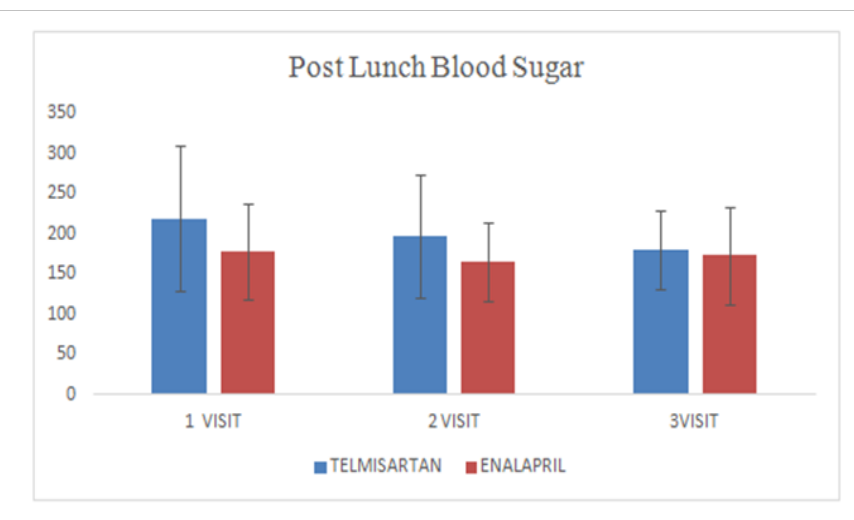

Figure 9 post lunch blood sugar.

Mean change of $\mathrm{HbAICin} \mathrm{Telmisartan} \mathrm{group} \mathrm{was} 7.6 \pm 2.80$

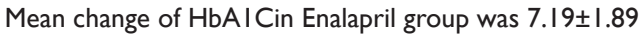

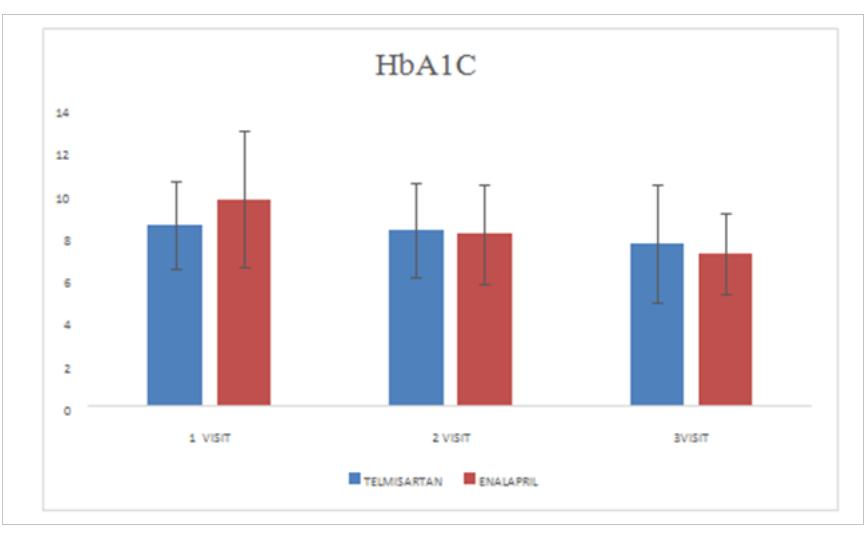

Figure $10 \mathrm{HbAIC}$.

Mean change of total cholesterol in Telmisartan group was 138.27 \pm 27.04

Mean change of total cholesterol in Enalapril group was I37.12 \pm 35.54

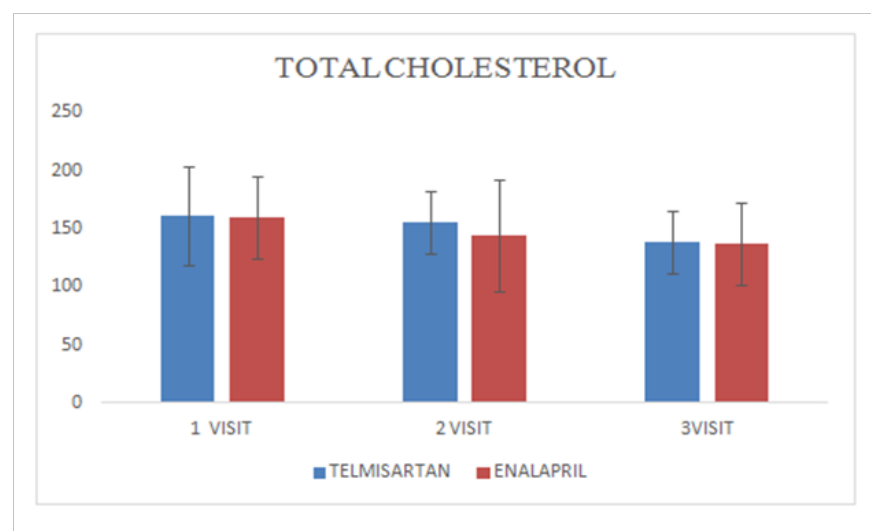

Figure II Total cholesterol.

Mean change of low density lipoprotein in Telmisartan group was 64.29 \pm 24.4

Mean change of low density lipoprotein in Enalapril group was $70.8 \pm 26.64$

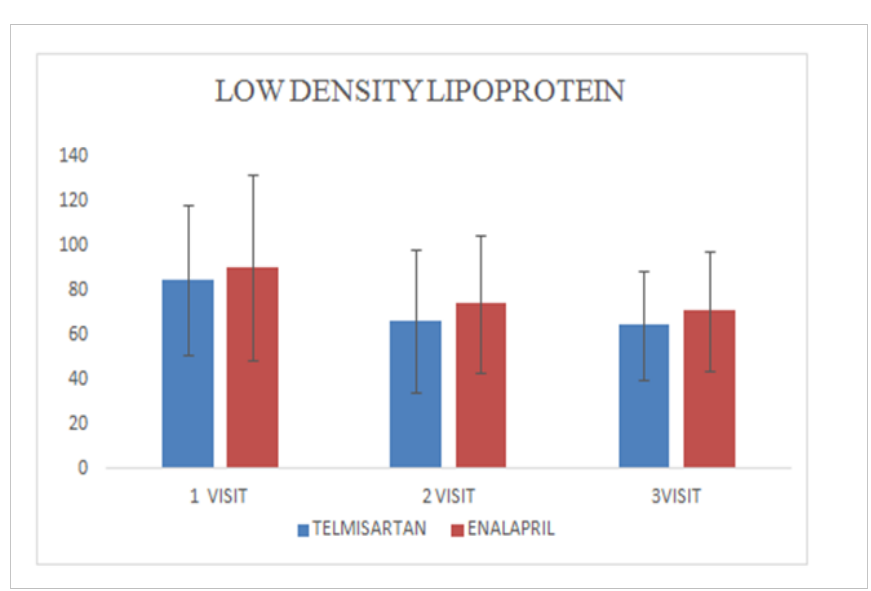

Figure 12 Low Density Lipoprotein.

Mean change of very low density lipoproteinin Telmisartan group was $29.33 \pm 9.7$

Mean change of very low density lipoprotein in Enalapril group was 29.5 \pm 8 .I I

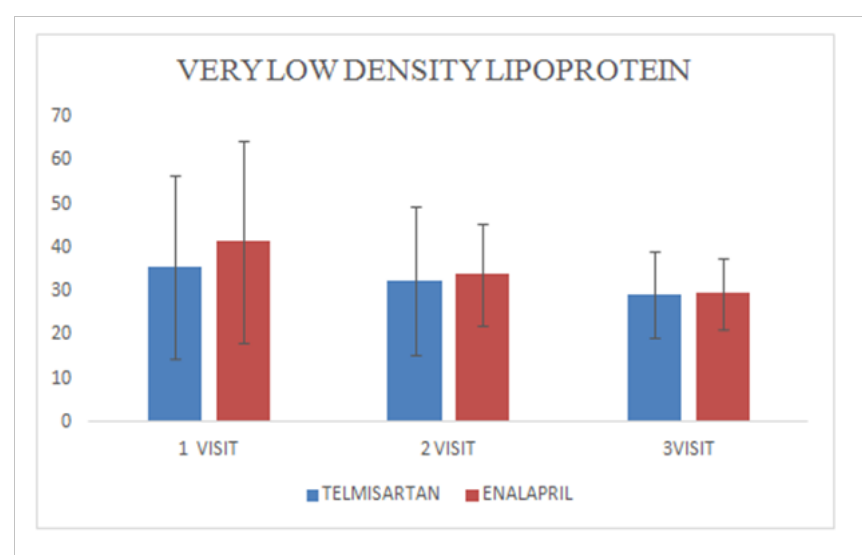

Figure 13 Very Low Density Lipoprotein.

Mean change of high density lipoproteinin Telmisartan group was 35.20 14.7 Mean change of high density lipoproteinin Enalapril group was $31.68 \pm 6.25$

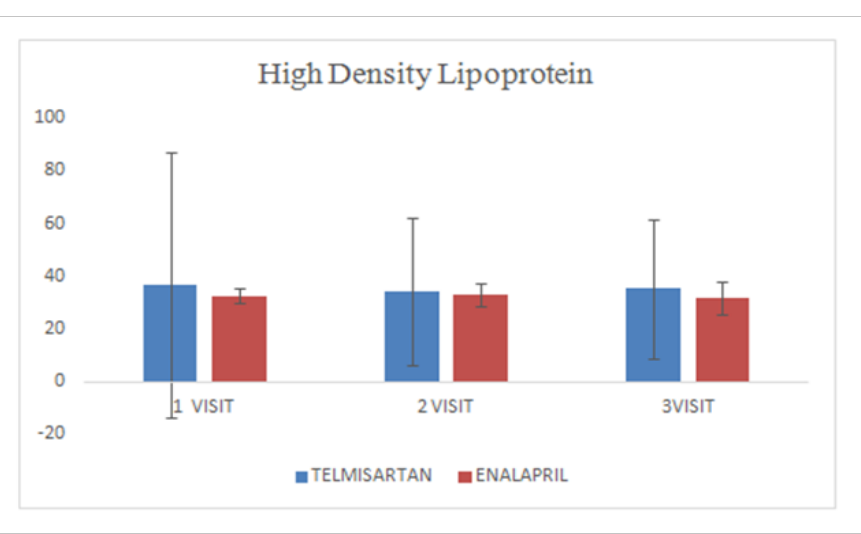

Figure 14 High density lipoprotein.

Mean changeof triglycerides in Telmisartan group was $135.77 \pm 40.73$

Mean change of triglycerides in Enalapril group was $144.68 \pm 29.07$ 


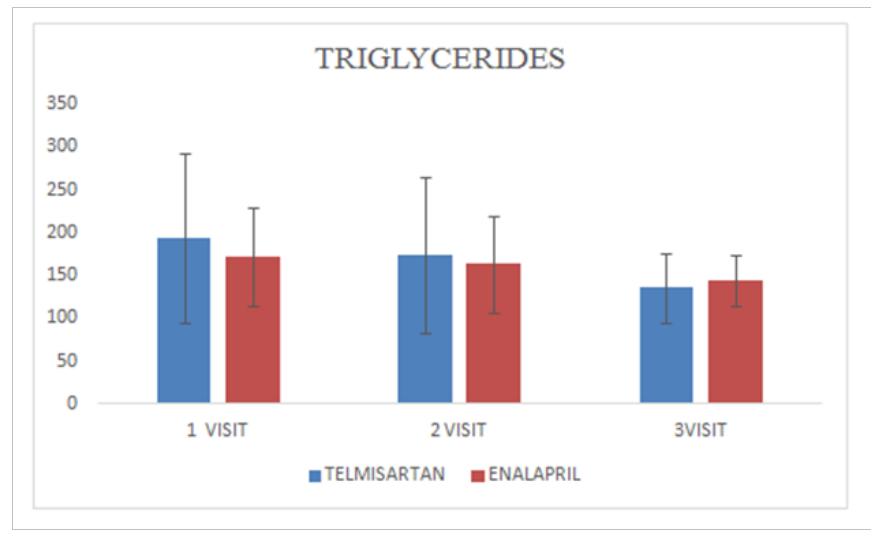

Figure 15 Triglycerides.

\section{Acknowledgments}

None.

\section{Conflicts of interests}

Author declares there is no conflict of interest.

\section{References}

1. Zmmet P, Cowie C, Ekoe JM, et al. Classification of diabetes mellitus and other categories of glucose intolerance. International Textbook of Diabetes Mellitus. 2003.

2. National Kidney Foundation. KDOQI clinical practice guidelines and clinical practice recommendations for diabetes and chronic kidney disease. Am J Kidney Dis. 2007;49(2 Suppl 2):S12-154.

3. Whiting D, Guariguta L, Weil C. IDF diabetes atlas: global estimates of the prevalence of diabetes for 2011 and 2030. Diabetes Res clin pract. 2011;94:311-321
4. Geiss LS, Li Y, Kirtland K, Increasing the prevalence of diagnosed diabetes-united states and Puerto Rico. 1995-2010. Morb Mortal Wkly $\operatorname{Rep}(M M W R) .2012 ; 61(45): 918$.

5. Burrows NR. Incidence of treatment for end-stage renal disease among individuals with diabetes in the U.S continues to decline. Diabetic care. 2010;33:73-77.

6. Brown NJ, Vaughan DE. Angiotensin-converting enzyme inhibitors. Circulation. 1998;97:1411-1420.

7. Wienen W, Hauel N, van Meel JC, et al. Pharmacological characterization of the novel nonpeptide angiotensin II receptor antagonist, BIBR 277. Br J Pharmacol. 1993;110(1):245-252.

8. Schmieder RE, Bakris G, Weir MR. Telmisartan in incipient and overt diabetic renal disease. Journal of nephrology. 2011;24(3):263-273.

9. Bhansali A, Bhadada SK, Kohli HS, et al. Anti-albuminuric efficacy of a combination of angiotensin converting enzyme inhibitor \& angiotensin receptor blocker in type $1 \mathrm{DM}$ with nephropathy. Indian J Med Res. 2010;132:42-47.

10. Barnett AH, Bain SC, Bouter P, et al. Angiotensin-receptor blockade versus converting-enzyme inhibition in type 2 diabetes and nephropathy. N Engl J Med. 2004;351(19):1952-1961.

11. Björck S, Mulec H, Johnsen SA, et al. selective aldosteron blockade with eplerenone reduces albuminuria in with type 2 patients diabetes. American society of nephrology. 2006;1(5):1.

12. Anthony H. Barnett, Stephen C Bain, Paul Bouter, et al., Angiotensin -receptor blockade versus converting - enzyme inhibition in type 2 diabetes and nephropathy". N Engl J Med. 2004;51:1952-1961.

13. Lacourciere Y, Belanger A, Godin C, et al. Long-term comparison of losartan and enalapril on kidney function in hypertensive type 2 diabetics with early nephropathy. Kidney It. 2000;58:762-769. 